\title{
True prevalence of twin HDV-HBV infection in Pakistan: a molecular approach
}

\author{
Asad U Khan ${ }^{1 \dagger}$, Muhammad Waqar ${ }^{1 \dagger}$, Madiha Akram², Mehnaz Zaib², Muhammad Wasim³, Shahzad Ahmad', \\ Zeeshan Niaz', Sajid Ali ${ }^{1}$, Haider Ali ${ }^{1}$, Muhammad Idrees ${ }^{4^{*}}$ and Mohammad A Bajwa ${ }^{5}$
}

\begin{abstract}
Hepatitis Delta Virus (HDV) infects only patients that are already infected by hepatitis B virus (HBV) because this is sub satellite virus which depends on and propagate only in the presence of HBV. HDV causes co-infection or super infection with sever complication as compared to only HBV infection. No study on molecular level on HDV is available from this region; therefore, the aim of this study was to found out the molecular epidemiology of HDV (as a co-infection with HBV) in different geographical regions of Pakistan.

Total $228 \mathrm{HBs} A g$ positive samples were received for the study from different geographical regions of the country. Only HBV DNA PCR positive samples were further utilized for the presence of HDV RNA. For this purpose, HDV RNA and HBV DNA was extracted and amplified using reverse transcriptase polymerase chain reaction (RT-PCR), nested $P C R$ and real-time PCR.

Out of the total $228 \mathrm{HBsAg}$ positive samples, HBV DNA was detected in total 190 (83.3\%) samples belonged to different patients. Of these 190 patients, HDV RNA was observed in 53 (28\%) patients. Of the 53 HDV positive cases, 37 (69.8\%) were males and 16 (30.2\%) were female patients. The percentage of dual infection was found higher significantly $(p<0.05)$ in male patients as compared to female patients. Total $41(26.8 \%)$ patients were below 40 years and 13 (31.7\%) were above 40 years of age. No significant difference was seen in patients with ages above or below 40 years. In the provinces of Sindh, Khyber Pakhtoonkhaw and Punjab the observed prevalence of HDV was $67 \%, 6 \%$ and $4 \%$ respectively.

In conclusion, the HDV infection is not uncommon in Pakistan and its prevalence is higher significantly in the Province of Sindh $(p<0.01)$ and male six $(p<0.05)$.
\end{abstract}

\section{Introduction}

Hepatitis Delta virus (HDV) infection is present globally and infects human being already infected by Hepatitis B virus (HBV). Hepatitis Delta is mostly present in Africa; South America, Romania, Russia and the Mediterranean region included Southern Italy [1]. HDV was first discovered by Rizzetto in the patients that were already infected by HBV in year 1980 [2]. HDV is a sub-satellite virus associated with $\mathrm{HBV}$ to cause severe acute and chronic forms of liver infection [3]. Tthe particle size of HDV is about 36-nm that require hepatitis B surface antigen (HBsAg) for their enveloped and transmission [4]. The HDV genome is a circular, negative sense,

\footnotetext{
* Correspondence: idreeskhan96@yahoo.com

† Contributed equally

${ }^{4}$ Division of Molecular Virology, CEMB, University of the Punjab Lahore-

53700, Pakistan

Full list of author information is available at the end of the article
}

single-strand RNA, which is approximately 1700 nucleotides in length [5]. These nucleotides is assemble with two viral proteins HD Ag-S and HDAg-L to form a ribonucleoprotein [6]. These Two Hepatitis D Ag proteins are translated from viral mRNA and this process is called RNA editing [7]. The dual infection of HBV and HDV occurs in the form of co-infection or as a superinfection. The Super infection of HDV with HBV caused a progressive chronic liver disease up to $(80 \%)$, which further enhances liver cirrhosis and hepatocellular carcinoma (HCC). Co-infection by both HBV and HDV viruses causes more severe acute liver disease and is a higher risk for the development of fulminate hepatitis compared to only HBV infected patients [8].

It has been estimated that approximately $5 \%$ of HBV carriers are co-infected with HDV, leading to an estimated 15 million persons infected with HDV worldwide [9]. HDV infection has a worldwide distribution, but its
C Biomed Central

() 2011 Khan et al; licensee BioMed Central Ltd. This is an Open Access article distributed under the terms of the Creative Commons Attribution License (http://creativecommons.org/licenses/by/2.0), which permits unrestricted use, distribution, and reproduction in any medium, provided the original work is properly cited. 
frequency varies greatly throughout different geographic regions. It is highly endemic in the Middle East, in the Mediterranean area, in the Amazonian region, and in several African countries [10].

Several studies propose that most people acquired HDV infections through parenteral and sexual routes [11-13]. Furthermore the reported seroprevalence of HDV infection among HBV carriers is significantly higher in intravenous drug users (IDU) compared to the non-IDU population [14].

In Pakistan, the prevalence of chronic HBV infection is estimated to be $16-57 \%$ in general population predominantly in younger males living in rural areas $[15,16]$. However, in these studies enzyme linked immunosorbant assay (ELISA) based assays were utilized for the estimation of this prevalence rate. For the true prevalence of HDV-HBV co-infection, we used molecular based methods such as PCR and real-time PCR for the detection of HBV DNA and HDV RNA in HBsAg positive samples from patients' different geographical regions of Pakistan.

\section{Methods}

\section{Source of Clinical Samples}

A total of $228 \mathrm{HBsAg}$ positive serum samples by enzyme linked immunosorbant assay (ELISA) were received at Genome Centre for Molecular Based Diagnostics \& Research (GCMBDR) Lahore, Pakistan from different geographical regions of the country for HBV DNA and/ or HDV RNA detection from January 2011 to March 2011. GCMBDR is a state of the art molecular based diagnostic facility that provides general public sensitive, specific and more reliable diagnostic tests on cost-tocost basis utilizing PCR and real-time PCR methods. All sera were stored in aliquots at $-70^{\circ} \mathrm{C}$ till was used for nucleic acid (DNA/RNA) isolation. Demographic characteristics, serological and biochemical data was available for 190 patients (male 121; female 69, mean age 42 years [range, 6-82 $\pm \mathrm{SD}$ ] years)) with chronic HBV infection and were thus included in the data analysis. These samples belonged to different provinces/geographical regions of Pakistan. Seventy were from Sindh, 66 belonged to Khyber Pakhtoonkhaw (KPK) and 54 were from Punjab. There was no need for separate written informed consent from subjects for this study, since this analysis was a part of the original protocol in a routine workup of Molecular Diagnostics.

\section{HBV DNA extraction and real-time PCR amplification}

Qualitative and quantitative detection of serum HBV DNA in all patients were performed by SmartCycler II real-time PCR (Cepheid, USA) with an internal RNA standard derived from the 5' UTR. The utilized kits for HBV DNA extraction and real-time PCR were done according to the procedures given in the kit protocols (Sacace Biotechnologies Italy). Sensitivity of the assay is $20 \mathrm{IU}$ per $\mathrm{ml}$ blood sample. Specificity of the assay is about $99 \%$.

\section{Extraction of HDV RNA and complementary DNA (cDNA) synthesis}

HDV RNA was extracted from $100 \mu \mathrm{L}$ serum sample using Gentra RNA isolation kit (Life Technologies, USA). About $50 \mathrm{ng}$ of the extracted RNA was reverse transcribed into cDNA with Molony-murin leukemia virus reverse transcriptase enzyme (Gibco BRL, Life Technologies USA). The thermal cycling was carried out in thermal cycler for 50 minutes at $37^{\circ} \mathrm{C}$. The reaction mixture for the preparation of $\mathrm{cDNA}$, for a single reaction contained $850 \mathrm{mM}$ Tris- $\mathrm{HCl}(\mathrm{pH} 8.3), 7.5 \mathrm{mM}$ $\mathrm{KCl}, 3 \mathrm{mM} \mathrm{MgCl} 2,0.1 \mathrm{M} \mathrm{DTT}, 10 \mathrm{mM}$ dNTPs and 200 $\mathrm{U}$ of MMLV reverse transcriptase enzyme. At the end of reaction, MMLV was heat inactivated at $95^{\circ} \mathrm{C}$ for 5 minutes.

\section{Qualitative detection}

The detection of the HDV cDNA was carried using nested PCR. The Qualitative detection of hepatitis Delta virus was done in two rounds. First round PCR was carried out in a PCR reaction tube that contained $8 \mu \mathrm{L}$ of mix I which having $2.5 \mathrm{mM} \mathrm{MgCl} 2,100 \mu \mathrm{M}$ concentration of each of the four deoxynucleotides, 10 pM of each outer sense nucleotides 695-718 \{5'CATGGTCCCAGCCTCCTCGCTGGC-3' $\}$ and outer anti-sense primers; nucleotides 873-896 \{5'CCGCGAGGAGGTGGAGATGCCATG-3'\} [17], and 1 $\mathrm{U}$ of Taq DNA polymerase Enzyme. In the thermal cycler, firstly the samples were incubated on $95^{\circ} \mathrm{C}$ for 2 min then it was followed by 35 cycles consisting of $95^{\circ} \mathrm{C}$ for $1 \mathrm{~min}, 64^{\circ} \mathrm{C}$ for $1 \mathrm{~min}$ and $72^{\circ} \mathrm{C}$ for $1 \mathrm{~min}$. The second round (nested PCR) PCR was also carried out in a reaction tube that contained $8 \mu \mathrm{L}$ of mix II which had $2.5 \mathrm{mM} \mathrm{MgCl} 2$, a $100 \mu \mathrm{M}$ concentration of each of the four deoxynucleotides, $10 \mathrm{pM}$ of each inner sense nucleotides 729-748 (5'-CAACATTCCGAGGGGA CCGT-3') and inner anti-sense primers nucleotides 846-865 (5'-GAAGGAAGGCCCTCGAGAACAAGA-3') [17]. For standard PCR to seen contamination we used the negative and reagent controls along with samples in each run. Finally the PCR products were electrophoresis on a $2 \%$ agarose gel prepared in $1 \times$ Tris-borate-EDTA (TBE) buffer, stained with ethidium bromide, and evaluated under UV transilluminator. The sizes of PCR products were estimated according to the migration pattern of a 50-bp DNA ladder (Fermentas Life Sciences). The sensitivity limit of this qualitative detection method was 10 copies per $\mathrm{ml}$ blood sample. 


\section{Statistical Analysis}

All the data was analyzed and the summary statistic was carried out by SPSS version 10.0 (a statistical package). Variables are given in the form of rates (\%). Chi Square test was used for categorical variables that measured association among categorical variables. Values of less than 0.05 were considered significant

\section{Results}

The study enrolments and patients' disposition are shown in Figure 1. One hundred and ninety patients with chronic HBV who fulfilled the study criteria were enrolled for this study out of total 288 consecutive HBsAg positive patients. Total 98 patients samples were excluded from the study either the volume of sera were not sufficient for testing $(n=19)$ or failed to meet inclusion criteria of the study $(n=79)$ as they were HBV DNA negative by real-time PCR. Out of 190 enrolled patients, $63.7 \%(n=121)$ were males and $36.3 \%(n=69)$ were females. The mean age was $38 \pm 11$ years. The sensitivity of the assay was excellent that is $20 \mathrm{IU}$ per $\mathrm{ml}$ blood sample.

Of the total 190 tested HBV positive cases, HDV RNA was detected in $58(28 \%)$ patients. Out the HDV positive patients, 37 were males and 16 were females. The rates of HDV positivity in both sexes are shown in table 1. The HDV RNA data was also analysed Province wise

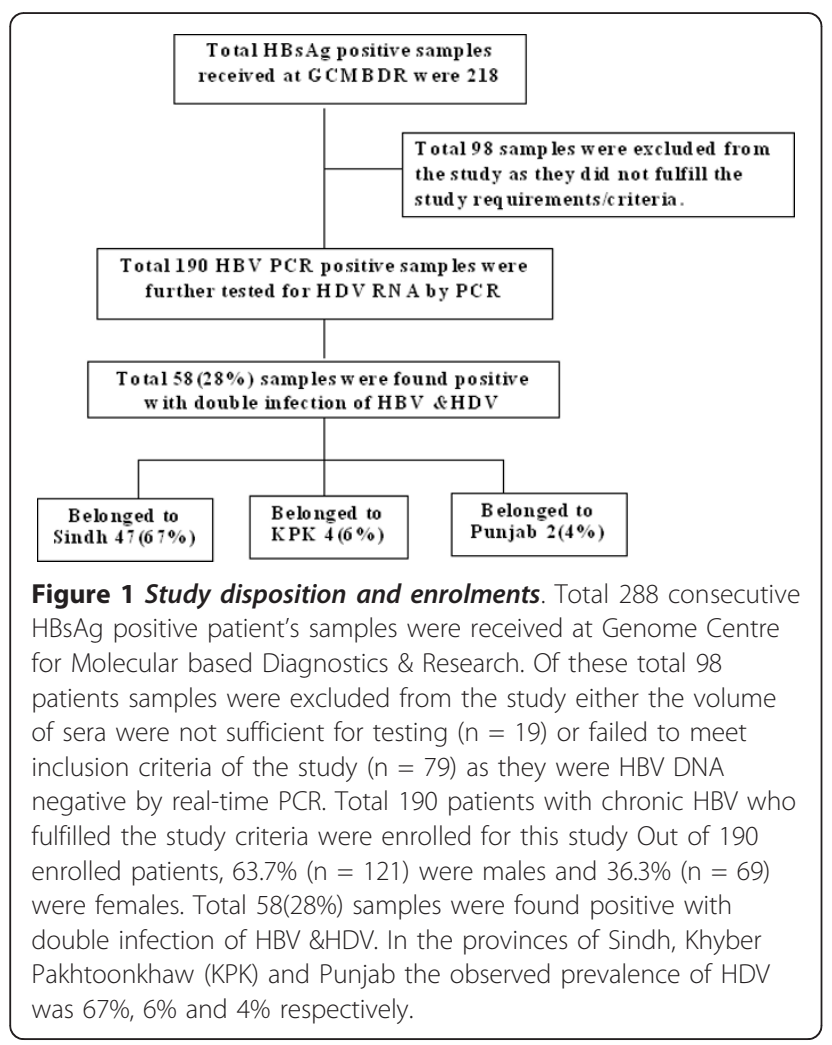

Table 1 Rate of HBV + HDV co-infection in male and female patients

\begin{tabular}{lllll}
\hline S.N & Gender & $\begin{array}{l}\text { Total samples HBV } \\
\text { positive }\end{array}$ & $\begin{array}{l}\text { Found positive } \\
\text { with HDV }\end{array}$ & Percentage \\
\hline 1 & Male & 121 & 37 & $31 \%$ \\
\hline 2 & Female & 69 & 16 & $23 \%$ \\
\hline & Total & $\mathbf{1 9 0}$ & $\mathbf{5 3}$ & $\mathbf{2 8 \%}$ \\
\hline
\end{tabular}

(Table 2). In the provinces of Sindh, Khyber Pakhtoonkhaw (KPK) and Punjab the observed prevalence of HDV was $67 \%, 6 \%$ and $4 \%$ respectively. The co-infection of HDV with HBV was higher significantly in the Province of Sindh as compared to Provinces of KPK and Punjab. No significant difference was seen in the rates of $\mathrm{HBV}+\mathrm{HDV}$ co-infection in patients below or above 40 years of ages (Table 3 ).

\section{Discussion}

HDV can be caused either as a co-infection (concomitant) in persons infected with HBV or as a super-infection (subsequent) in chronic HBV carriers. As it is now an established fact that HDV is a defective virus, containing particles of RNA nucleoprotein in virion-like form, present in patients with acute hepatitis B and chronic hepatitis that requires the presence of a hepadnavirus (HBV) for full replication. That is why for its penetration into the hepatocytes and assembly of virion, it needs the help of HBV that provides the viral coat surface antigen and can survive only in the presence of HBV (co-infection or/and super-infection). Here we report on the HDV-HBV co-infection or molecular epidemiology of HBV+HDV co-infection. Our study is the first one to describe the molecular epidemiology of HDV and its co-infection with HBV in different geographical regions of Pakistan. This is very important study as it describes the dual HBV-HDV infection using molecular methods. It has already been reported that in contrast to HBV mono-infection, HBV+HDV co-infection leads to exacerbation and rapid progression of chronic liver disease, hepatic failure, and deaths in patients $[18,19]$.

Table 2 Rate of HBV + HDV co-infection in different provinces of Pakistan

\begin{tabular}{lllll}
\hline S.N & province & $\begin{array}{l}\text { Total HBV DNA PCR } \\
\text { positive isolates }\end{array}$ & $\begin{array}{l}\text { Found } \\
\text { positive with } \\
\text { HDV }\end{array}$ & Percentage \\
\hline 1 & SINDH & 70 & 47 & $67 \%$ \\
\hline 2 & $\begin{array}{l}\text { KHYBER } \\
\text { PUKHTUN } \\
\text { KHWA }\end{array}$ & 66 & 4 & $6 \%$ \\
\hline 3 & PUNJAB & 54 & & $4 \%$ \\
\hline & Total & $\mathbf{1 9 0}$ & 2 & $\mathbf{2 8 \%}$ \\
\hline
\end{tabular}


Table 3 Rate of HBV + HDV co-infection in different patients age groups

\begin{tabular}{lllll}
\hline S. & $\begin{array}{l}\text { Age } \\
\mathbf{N}\end{array}$ & $\begin{array}{l}\text { Total HBV DNA PCR } \\
\text { positive isolates }\end{array}$ & $\begin{array}{l}\text { Found positive } \\
\text { with HDV }\end{array}$ & Percentage \\
\hline 1 & $\begin{array}{l}\text { Below } \\
40 Y\end{array}$ & 149 & 40 & $26.8 \%$ \\
\hline 2 & $\begin{array}{l}40 Y \& \\
\text { above }\end{array}$ & 41 & 13 & $31.7 \%$ \\
\hline & Total & $\mathbf{1 9 0}$ & $\mathbf{5 3}$ & $\mathbf{2 7 . 9 \%}$ \\
\hline
\end{tabular}

Several important findings emerged from the results of this study. The first finding of the current study showed that more than $83 \%$ of the HBsAg positive patients by ELISA were also positive by HBV DNA PCR. HBV + HDV co-infection was observed in $28 \%$ HBV DNA positive patients that is very alarming. This is the true prevalence of active HDV infection in HBV DNA positive cases. The previously conducted studies on the seroprevalence of HDV infection in Pakistan have reported the prevalence of antibodies against HDV (HDV-Ab) of $16 \%$ and $57 \%$, respectively $[15,16]$. However these studies were based on ELISA methods that might give both false positive and false negative results. In spite of this high prevalence, no data on molecular epidemiology of HDV in Pakistan are available. The prevalence of HDV positive cases obtained in this study is extremely high. More recently a high endemicity of HDV in Cameroonian populations was reported by Foupouapouognigni and colleagues [20].

Next important finding of the study is the observation that HDV rate is significantly high $(\mathrm{p}<0.001)$ in male (69.81\%) as compared to female $(30.18 \%)$ patients. However the chances of this co-infection is same in all age groups as no significant difference was seen for the rates of co-infection in patients with ages below or above 40 years. This finding of the current study is contrary to the finding of another study from Pakistan where HDV was predominant in young population [15].

Another important finding of the present study is the observation that rates of HDV is significantly high $(\mathrm{P}<$ 0.001) in ethnic group Sindhi as compared to Punjabi and Pashtoon races. Is Sindhi racing an independent risk factor for acquiring HDV, is question marked? To correctly answer this question, we recommend further conformation of this observation by other studies with large number of patients. In our study in all three groups the baseline characteristics of patients were similar however we were unable to establish the exact mode of contamination that may play a major role in this high rate of HDV in Sindh. No study on correlation of HDVHBV co-infection with ethnic group is available from this region.
Also so far no epidemiological survey at molecular level has been documented in Pakistan to investigate the prevalence of double HBV plus HDV hepatitis infection hence this study provides new insights and dimensions for the molecular virologists to carry out investigations on patients having this double hepatitis related liver disorders. Further we believe that the results of the current study enrich the limited information on co-infection and molecular epidemiology of HDV in the region.

\section{Conclusion}

Our study showed a higher prevalence of HDV in HBV DNA positive patients that highlights the importance of screening for HDV infection in HBV carriers. Its prevalence is higher significantly in the Province of Sindh and male six. Clinicians particularly gastroenterologist, hepatologists and other medical and practitioners should be made aware of the danger of twin infection with HDV and HBV. Further studies, with full genome characterization of different HDV strains are required.

\section{Acknowledgements}

All the HBsAg positive samples were provided by Genome Centre for Molecular Based Diagnostics \& Research (GCMBDR). The molecular diagnosis was done at GCMBDR free of charges. Also thanks to all the clinicians and patients for their cooperation in the study.

\section{Author details}

'Department of Microbiology, Hazara University Mansehra, Pakistan. ${ }^{2}$ Genome Center for Molecular Diagnostics \& Research, $945 \mathrm{~J}-$ II Johar Town Lahore, Pakistan. ${ }^{3}$ Khyber Medical University, Hayatabad Road, Peshawar, Khyber Pakhtoonkhaw, Pakistan. ${ }^{4}$ Division of Molecular Virology, CEMB, University of the Punjab Lahore-53700, Pakistan. ${ }^{5}$ Department of Gastroenterology, Sheikh Zayed Medical Complex, Lahore, Pakistan.

\section{Authors' contributions}

AUK and MW conceived the study. AUK and MW collected the samples and performed PCRs and other the molecular analysis. MA and $M Z$ helped in molecular analysis. MW, SA, ZN, SA, HN and MAB helped in literature search and drafting manuscript. Ml critically reviewed the manuscript and revised it. All the authors read and approved the final manuscript.

\section{Competing interests}

The authors declare that they have no competing interests.

Received: 25 July 2011 Accepted: 4 September 2011

Published: 4 September 2011

\section{References}

1. World Health Organization Hepatitis Delta. [http://www.searo.who.int/EN/ Section10/Section1027_9489.htm], [WHO/CDS/CSR/NCS/2001.1].

2. Rizzetto M, Canese MG, Gerin JL, London WT, Sly DL: Transmission of the hepatitis B virus-associated delta antigen to chimpanzees. J Infect Dis 1980, 141:590-602.

3. Gal FL, Gault E, Rapault MP, Serpaggi J, Trinchet JC, Gordien E: Eight clade for hepatitis delta virus. Emerging Infect Dis 2006, 12:1447-1450.

4. Gerin $J L$, Cassey JL, Purcell RH: Hepatitis delta virus. In Viral Hepatitis. Edited by: Hollinger FB, Purcell RH,Gerin JL. Philadelphia: Lippincott Williams and Wilkins; 2002:169-182.

5. Radjef N, Gordien E, Ivaniushina V, Gault E, Anais P, Drugan T: Molecular phylogenetic analyses indicate a wide and ancient radiation African hepatitis delta virus, suggesting a deltavirus genus of at least seven major clades. J Virol 2004, 78:2537-2544. 
6. Gal FL, Gordien E, Affolabi D, Hanslik T, Alloui C, Dény P: Quantification of hepatitis delta virus RNA in serum by consensus real-time PCR indicates different patterns of virological response to interferon therapy in chronically infected patients. J Clin Micro 2005, 43:2363-2369.

7. Polson AG, Bass BL, Casey JL: RNA editing of hepatitis delta virus antigenome by dsRNA-adenosine deaminase. Nature 1996, 380:454-456.

8. Yamaguchi Y, Deléhouzée S, Handa H: HIV and hepatitis delta virus: evolution takes different paths to relieve blocks in transcriptional elongation. Microb Infect 2002, 4:1169-1175.

9. Farci P: Delta hepatitis: an update. J Hepatol 2003, 39(Suppl 1):S212-S219.

10. Husa P, Linhartová A, Nemecek V, Husová L: Hepatitis D. Acta Virol 2005, 49:219-225.

11. Liaw YF, Chiu KW, Chu CM, Sheen IS, Huang MJ: Heterosexual transmission of hepatitis delta virus in the general population of an area endemic for hepatitis B virus infection: a prospective study. J Infect Dis 1990, 162:1170-1172

12. Novick DM: Hepatitis $D$ virus and human immunodeficiency virus antibodies in parenteral drug abusers who are hepatitis B surface antigen positive. J Infect Dis 1988, 158:795-803.

13. Stroffolini T: Incidence and risk factors of acute Delta hepatitis in Italy: results from a national surveillance system. SEIEVA Collaborating Group. J Hepatol 1994, 21:1123-1126.

14. Chang Sy, Yang CL, Ko WS, Liu WC, Lin CY, Wu CS, Su YC, Chang SF, Chen MY, Sheng WH, Hung CC, Chang SC: Molecular Epidemiology of Hepatitis D Virus Infection among Injecting Drug Users with and without Human Immunodeficiency Virus Infection in Taiwan. J Clin Microbiol 2011, 49:1083-1089.

15. Mumtaz K, Hamid SS, Adil S: Epidemiology and clinical pattern of hepatitis delta virus infection in Pakistan. J Gastroenterol Hepatol 2005, 20:1503-7.

16. Zuberi BF, Quraishy MS, Afsar S: Frequency and comparative analysis of hepatitis D in patients seeking treatment for hepatitis B. J Coll Physicians Surg Pak 2006, 16:581-4.

17. Makino S, Change MF, Sheikh CK, Kamahora T, Vannier DM, Govindarejin S: Molecular cloning and sequencing of a human delta virus RNA. Nature 1987, 329:343-346.

18. Novick DM: Hepatitis $D$ virus and human immunodeficiency virus antibodies in parenteral drug abusers who are hepatitis B surface antigen positive. J Infect Dis 1988, 158:795-803.

19. Stroffolini T: Incidence and risk factors of acute Delta hepatitis in Italy: results from a national surveillance system. SEIEVA Collaborating Group. J Hepatol 1994, 21:1123-1126.

20. Foupouapouognigni Y, Noah DN, Sartre MT, Njouom R: High Prevalence and Predominance of Hepatitis Delta Virus Genotype 1 Infection in Cameroon. J Clin Microbiol 2011, 49:1162-1164.

doi:10.1186/1743-422X-8-420

Cite this article as: Khan et al: True prevalence of twin HDV-HBV

infection in Pakistan: a molecular approach. Virology Journal 2011 8:420

\section{Submit your next manuscript to BioMed Central and take full advantage of:}

- Convenient online submission

- Thorough peer review

- No space constraints or color figure charges

- Immediate publication on acceptance

- Inclusion in PubMed, CAS, Scopus and Google Scholar

- Research which is freely available for redistribution 